\title{
DISTRIBUTION OF BROMOURACIL IN THE PYRIMIDINE OLIGONUCLEOTIDES OF DROSOPHILA DNA
}

ROSE M. RIZKI AND T. M. RIZKI

Department of Zoology, The University of Michigan, Ann Arbor, Michigan f8rof (U.S.A.)

(Received March I ith, I975)

(Revision received June 7 th, 1975)

(Accepted June Ioth, 1975)

\section{SUMMARY}

DNA was isolated from Drosophila melanogaster larvae fed radioactive thymidine (TdR), bromodeoxyuridine (BUdR), or one of these nucleosides together with 5-fluorouracil (FU) under identical conditions. The four DNA samples designated T-DNA, B-DNA, T(F)-DNA, and B(F)-DNA respectively were hydrolyzed with formic acid-diphenylamine, and the pyrimidine oligonucleotides of various chain lengths (isostichs) were fractionated by DEAE-cellulose chromatography. The distributions of the labeled thymine and bromouracil (BU) residues among the pyrimidine isostichs were determined, and compared for the four DNAs. These comparisons indicated the following:

( $I$ ) Similarity of T-DNA and T(F)-DNA with respect to labeled thymine distribution among the pyrimidine isostichs (using the mononucleotide to pentanucleotide tracts for statistical comparisons) showed that TdR entering DNA synthesis via the salvage pathway has the same distribution whether the synthetic pathway is operating normally or is inhibited by $\mathrm{FU}$ treatment.

(2) Quantitative comparison of the distribution of BU among the isostichs of B-DNA and B(F)-DNA with the distribution of labeled thymine in T-DNA showed significant differences, indicating that the organism does not accept BUdR indiscriminately at all thymine sites for DNA synthesis.

(3) Comparison of the distribution of BU in B-DNA and B(F)-DNA showed that isostichs $I$ and 3 differ significantly. The elution profiles of the isostichs also differed qualitatively between these DNAs. This analysis confirms differential incorporation of BUdR into Drosophila DNA in the presence of a thymidylate inhibitor.

The observations on BUdR incorporation in Drosophila DNA have been discussed with relation to the high frequency of somatic cell mutations induced in imaginal disc cells by treatment with the analog in the presence of inhibitors of thymidylate synthetase.

Abbreviations: BU, 5-bromouracil; BUdR, 5-bromodeoxyuridine: dBUTP, bromodeoxyuridine triphosphate; dTMP-thymidine monophosphate; dTTP, thymidine triphosphate; FU, 5-fluorouracil; FUdR, 5-fluorodeoxyuridine; MLV, murine leukemia virus; TdR, thymidine. DNA samples: B-DNA, from larvae fed BUdR; $B(F)-D N A$, from larvae fed BUdR $+F U$; $T-D N A$, from larvae fed TdR; T(F)-DNA, from larvae fed TdR+FU. 


\section{INTRODUCTION}

Numerous reports on the biological effects of BUdR on vertebrate cells have appeared within the past several years. The $T \mathrm{~d} R$ analog reversibly inhibits specific differentiative features of cultured cells ${ }^{11,31}$, induces C-type particles and other viruses ${ }^{1,17}$, and suppresses tumorigenicity in mouse melanoma cells ${ }^{27}$. Incorporation of BUdR in DNA is correlated with these phenomena and several hypotheses attempt to reconcile temporary alterations in cellular functions with molecular modifications at the DNA level: errors in transcription of $\mathrm{BUdR}$-containing $\mathrm{DNA}^{14}$, altered binding of regulator proteins to DNA that contains $B U d R^{16}$, and incorporation of $B L d R$ in specific regions of DNA followed by loss of this DNA ${ }^{15}$. Alternatively, SCHLBERT ANI $\mathrm{J}_{\mathrm{ACOB}}{ }^{26}$ have suggested that reversible alterations in cellular properties might be due to metabolic effects of BUdR rather than its incorporation in DNA. Since the continued presence of $B L d R$ in the culture medium is required to maintain an altered cell phenotype in these studies, the role of BUdR as a mutagen has been excluded from consideration. On the other hand, the mutagenicity of BLdR for cultured mammalian cells has been demonstrated recently ${ }^{9}$, and the possibility that BUdR alters the differentiation of Drosophila imaginal disc cells in wivo by causing changes at the DNA informational level has also been raised ${ }^{19,22}$.

Although spontaneous mistakes in base pairing during DNA replication occur, the presence of the brominated analog of thymine enhances their frequency at a significant level. Replacement of the 5-methyl group of thymine by a bromine atom increases the frequency of the enolic form of the base which may pair with guanine rather than adenine during DNA replication, and as a result of these mispairings, "transitions" arise such that an adenine-thymine pair is replaced by a guanine-cytosine pair in DNA, or vice iersa ${ }^{13}$. The experimental studies in microbial systems support the "transition" hypothesis of BU mutagenesis. There is, however, little evidence that a simple mispairing process underlies the phenomenon ${ }^{12}$. The question whether all thymine sites in the DNA of the mammalian cell are equally accessible to BL was raised by SIMON ${ }^{28}$. On the basis of the growth characteristics of HeLa cells plated with various concentrations of $B U d R, F U d R$ and $T d R$, he proposed that 50 to $75 \%$ of the thymine sites in DNA will accept BU as readily as thymine; some of the remaining sites prefer thymine but will accept $\mathrm{BU}$ if the availability of the former is reduced as is the case when $\mathrm{I} U \mathrm{dR}$ is added to the culture medium; 5 to $10 \%$ of the sites require thymine, and in its absence, DNA synthesis will cease. A subsequent comparison of the nucleoside incorporation patterns in the DNA of HeLa cells was inconclusive ${ }^{33}$, but the suggestion merits reconsideration in view of the effects of BUdR in Drosophila in vivo ${ }^{18}$.

If $\mathrm{BU}$ is considered a thymine analog, it is reasonable to expect that its distribution in DNA should follow the same distribution as that of thymine residues along the DNA molecule. Therefore, the hypothesis that $\mathrm{BU}$ is a thymine analog can be tested by comparing the distribution of $\mathrm{BC}$ and thymine in the pyrimidine isostichs (oligonucleotides) separated from DNA samples labeled with these pyrimidine bases under the same experimental conditions. Depurination of DNA with formic aciddiphenylamine releases the pyrimidine oligonucleotides ${ }^{*}$ which can be fractionated according to chain length on DEAE-cellulose columns. The procedures can be used quantitatively for comparing DNA samples obtained from various sources ${ }^{6,7,25}$, and 
can also be used to compare the distribution of pyrimidine bases that have been incorporated in DNA via the salvage pathway as nucleosides, BUdR and TdR. BUdR is not destroyed by the acid hydrolysis ${ }^{3}$. For the present study, Drosophila DNA was labeled with TdR or BUdR by feeding the larvae radioactive nucleosides in the presence or in the absence of a thymidylate inhibitor, and the mode of incorporation of the labeled nucleosides among the pyrinidine isostichs was then compared.

MATERIALS AND METHODS

The methods for feeding TdR and BUdR to D. melanogaster (Oregon-R) larvae, and isolation of DNA samples were the same as those used in earlier studies ${ }^{18,19}$. In order to assure maximum differences between $\mathrm{B}$-DNA and $\mathrm{B}(\mathrm{F})$-DNA, the larvae were allowed to remain on the feeding solutions for $24 \mathrm{~h}$ prior to DNA isolation. Concentrations that were demonstrated to be morphogenically effective in earlier studies were used: BUdR and TdR-6.5 $1 \mathrm{IO}^{-4} \mathrm{M} ; \mathrm{FU}-\mathrm{I} . \mathrm{I} 5 \cdot 1 \mathrm{I}^{-3} \mathrm{M}$.

Each labeled sample of Drosophila DNA ( $\sim 0.5 \mathrm{mg})$ together with $25 \mathrm{mg}$ calf thymus DNA was hydrolyzed by the formic acid-diphenylamine procedure described by SPENCER et al.$^{30}$. The pyrimidine isostichs were separated on DEAE-cellulose columns utilizing a linear gradient of $\mathrm{LiCl}$ to $0.4 \mathrm{M}$ at $\mathrm{pH} 5.3$. When approximately I50-I 60 fractions ( $5 \mathrm{ml}$ ) had been collected, the column was washed with I $M \mathrm{LiCl}$ to release the longer pyrimidine stretches. A I-ml aliquot was removed from each fraction and used to determine absorbance at $260 \mathrm{~nm}$; the aliquot was then transferred to a scintillation vial and $\mathrm{Io} \mathrm{ml}$ of scintillation mixture was added for counting radioactivity ${ }^{18}$. An estimate of the frequency distribution of the pyrimidine isostichs was calculated by adding the individual readings (absorbance or $\mathrm{cpm}$ ) corresponding to each isostich component, and then dividing these values by the total absorbance or radioactivity recovered from the column.

RESULTS

In order ro verify that our use of the methods for separation of the pyrimidine oligonucleotides remained uniform throughout the duration of this investigation, the isostichs from calf thymus DNA were examined at three different times during the course of this study which extended over a period of 2 years. The mean values for the three analyses on calf thymus DNA are given in Table I, and comparison of these data with values from SPENCER et al. ${ }^{29}$ shows that their procedure is highly reproducible and justifies the use of calf thymus DNA as a carrier and a reliable marker for monitoring the relative elution pattern of the Drosophila isostichs.

A typical pyrimidine isostich profile of Drosophila DNA ([ $\left.{ }^{14} \mathrm{C}\right] \mathrm{TdR}$ label) cochromatographed with calf thymus DNA marker is given in Fig. I. As expected, the TdR-labeled isostichs parallel the faster eluting portion of each isostich profile since thymine nucleotides precede the cytosine nucleotides in release from the column. Three additional samples of Drosophila DNA (labeled with $\left[{ }^{3} \mathrm{H}\right] \mathrm{TdR}$ ) were fractionated, and data from these experiments are summarized in Table I. DNA from larvae given $\mathrm{FU}$ together with $\mathrm{TdR}$ did not differ from this distribution pattern.

Elution speeds of approx. $0.8 \mathrm{ml} / \mathrm{min}$ and DEAE columns $0.9 \times \mathrm{I} 2 \mathrm{~cm}$ were satisfactory for separation of the pyrimidine oligonucleotides labeled with $\mathrm{TdR}$ as 
TABLE I

PER CENT DISTRIBUTION OF PYRIMIDINE ISOSTICHS

The calf thymus values represent the mean of three analyses and have been included for purposes of comparison with the distribution obtained for four samples of Drosophila DNA. In this table standard errors have been tabulated to indicate the variability between independent analyses of calf thymus DNA (UV absorption) and independent samples of Drosophila DNA (radioactivity); they are not intended for statistical purposes (see text).

\begin{tabular}{|c|c|c|c|}
\hline Isostich & Calf thymus & & Drosophila \\
\hline I & $22.9 \pm 0.57$ & $22 \cdot 4^{\mathrm{a}}$ & $23.05 \pm 0.3^{8}$ \\
\hline 2 & $21.8 \pm 0.86$ & $2 \mathrm{r} . \mathrm{O}$ & $23.52 \pm 0.20$ \\
\hline 3 & I6.4 土0.28 & I6.6 & $18.83 \pm 0.20$ \\
\hline 4 & I2.1 上 0.33 & 12.2 & $12.92 \pm 0.04$ \\
\hline 5 & $8.3 \pm 0.35$ & 8.2 & $8.5 \mathrm{x} \pm 0.16$ \\
\hline 6 & $6.0 \pm 0.3^{8}$ & 6.4 & $5 . \mathrm{I} 3 \pm 0 . \mathrm{II}$ \\
\hline 7 & $4.1 \pm 0.49$ & 4.2 & $2.8 \mathrm{x} \pm 0.20$ \\
\hline 8 & $2.6 \pm 0.23$ & 3.0 & $1.66 \pm 0.05$ \\
\hline 9 & $1.6 \pm 0.12$ & & $1.05 \pm 0.02$ \\
\hline IO & & & $0.83+0.13$ \\
\hline I I & & & $0.3^{8}+0.04$ \\
\hline Longer & 4.3 土 0.08 & 6.0 & $1.09 \pm 0.05$ \\
\hline
\end{tabular}

a SPENCER et al. ${ }^{29}$ spectrophotometric data converted to per cent values.

illustrated in Fig. $\mathbf{I}$. These conditions were therefore adopted for the first fractionations of $\mathrm{B}$-DNA and $\mathrm{B}(\mathrm{F})$-DNA hydrolysates. The BU-containing isostichs trailed the $\mathrm{UV}$-absorbing calf thymus isostichs in these samples as anticipated, but resolution was generally limited to five or six BU-labeled peaks. There was, however, a clear

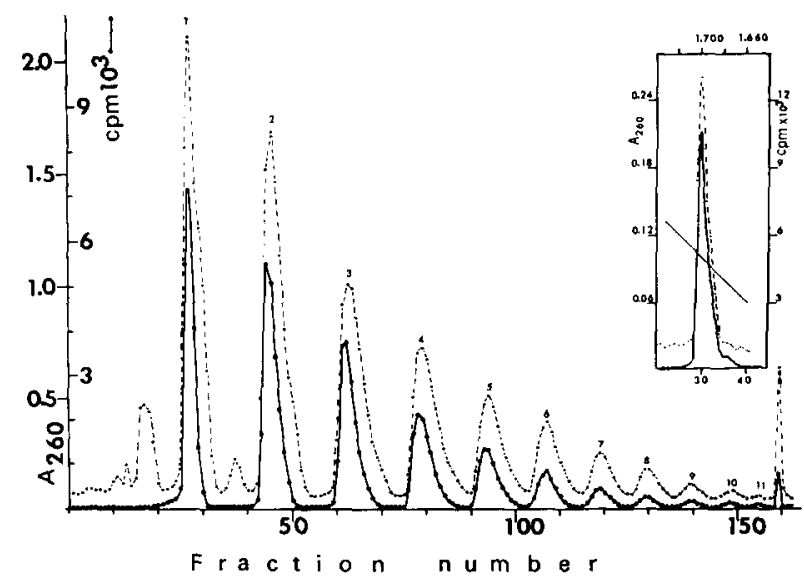

Fig. 1. Chromatography of a formic acid-diphenylamine hydrolysate of $\left[{ }^{14} \mathrm{C}\right] \mathrm{TdR}$ labeled Drosophila DNA and calf thymus DNA. The calf thymus pyridimine isostichs have been numbered: peak I contains the mononucleotides, peak 2 consists of dinucleotides, and so forth. The column (o.9 $\times$ $\mathrm{I} 2 \mathrm{~cm}$ ) contained $1.2 \mathrm{~g}$ DEAE-cellulose $\left(325 \mathrm{mesh}, \mathrm{Cl}^{-}\right.$form) buffered in o.or $M$ lithium acetate. A linear gradient of $\mathrm{LiCl}$ to $0.4 M$ was used to elute the pyrimidine isostichs at a speed of $0.8 \mathrm{ml} / \mathrm{min}$; 5 -ml fractions were collected and the $A_{260}$ readings (broken line) on $\mathrm{I}$ ml aliquots of each fraction were taken with a Zeiss spectrophotometer; radioactivity (solid line) of each aliquot was counted in a Nuclear Chicago "Unilux I" at a counting efficiency of $43 \%$. Fractions $158-160$ were eluted with I $M \mathrm{IiCl}$ to complete the run. At age $72 \mathrm{~h}$ Drosophila larvae were transferred to an aqueous solution of $\mathrm{TdR}\left(6.5^{\cdot} \mathrm{IO}^{-4} \mathrm{M}\right.$ containing $\left[{ }^{2-{ }^{14} \mathrm{C}}\right] \mathrm{TdR}$, specific activity $43.7 \mathrm{mCi} / \mathrm{mole}$, at $4^{\cdot 10^{-4}}$ $\mathrm{mCi} / \mathrm{ml}$ ). DNA was isolated $24 \mathrm{~h}$ later; the insert is a $\mathrm{CsCl}$ density gradient of this DNA sample which was then refrigerated in a saline-citrate solution until hydrolysis. The sample $(0.3 \mathrm{mg})$ was reprecipitated and dissolved in distilled $\mathrm{H}_{2} \mathrm{O}$ prior to hydrolysis together with $25 \mathrm{mg}$ calf thymus DNA. 
indication of a difference between the hydrolysates of B-DNA and B(F)-DNA in that the peaks of radioactivity in isostichs 3 and longer of the latter samples tended to elute further behind each marker peak than did the isostichs in B-DNA samples. In an effort to improve resolution of these differences, column length was extended to $25 \mathrm{~cm}$ and elution speed reduced to $0.3 \mathrm{ml} / \mathrm{min}$ for additional B-DNA and B(F)-DNA samples. Isostich profiles of Drosophila DNAs labeled with $\left[{ }^{3} \mathrm{H}\right] \mathrm{BUdR}$ and chromatographed under these conditions are presented in Figs. 2 and 3 . The DNA samples for these analyses were obtained from a single collection batch of larvae fed simultaneously with the same $\left[{ }^{3} \mathrm{H}\right] \mathrm{BUdR}$ solution, the $\mathrm{B}(\mathrm{F})$-DNA larvae receiving $\mathrm{FU}$ in addition.

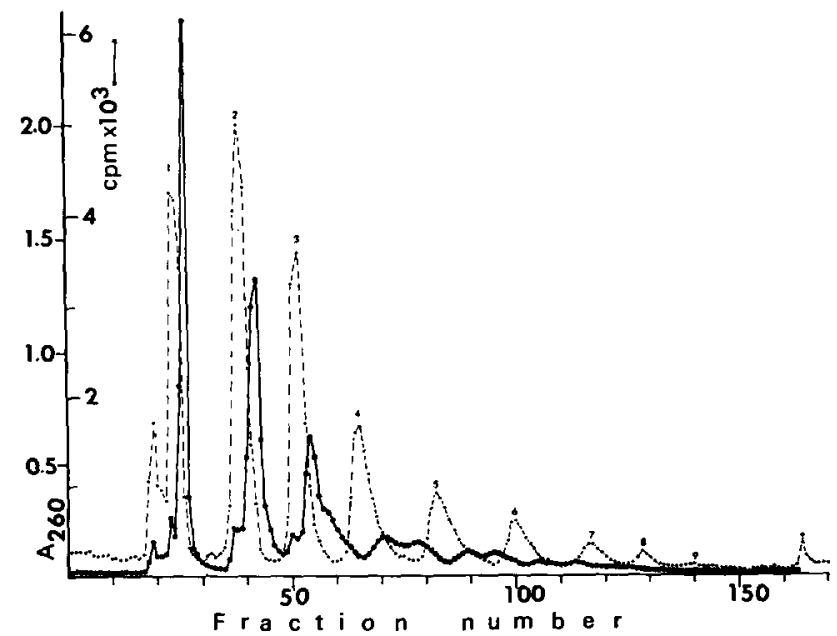

Fig. 2. Pyrimidine oligonucleotides from Drosophila B-DNA cochromatographed with calf thymus marker. Procedures as in Fig. I, except column length was extended to $25 \mathrm{~cm}$ and elution speed was reduced to $0.3 \mathrm{ml} / \mathrm{min}$. Larvae from a single collection batch were used to obtain this B-DNA $(0.7 \mathrm{mg})$ sample simultaneously with the B(F)-DNA ( $1.2 \mathrm{mg}$ ) sample for Fig. 3. At age $72 \mathrm{~h}$ the larvae were separated into two groups and placed on an aqueous solution of BUdR $\left(6.5 \cdot{ }^{-4} M^{-4}\right.$ containing $50 \mu \mathrm{Ci} / \mathrm{ml}\left[{ }^{3} \mathrm{H}\right] \mathrm{BUdR}$, specific activity $28.6 \mathrm{Ci} / \mathrm{mmole}$ ).

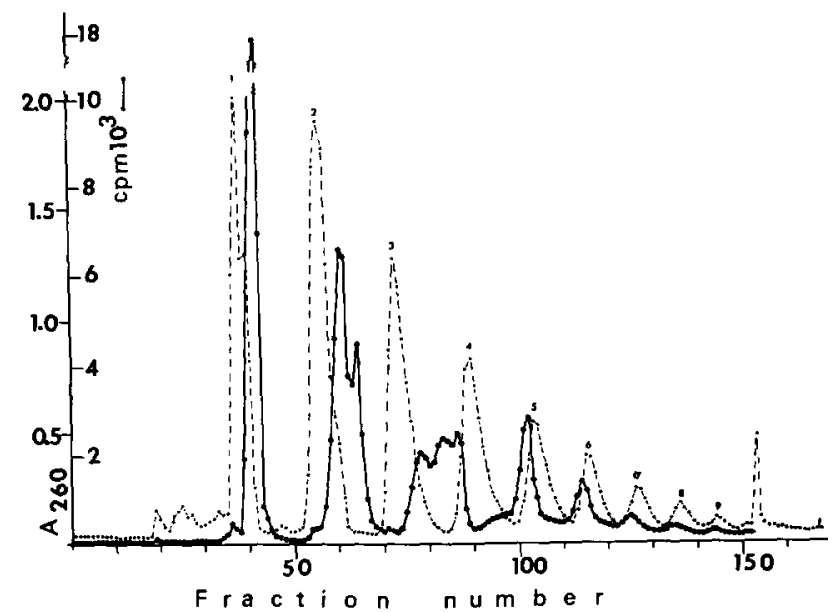

lig. 3. Elution profiles of pyrimidine isostichs from Drosophila $B(F)-D N A$ and calf thymus carrier DNA. Details as in Fig. 2. 
The tritiated $\mathrm{BU}$-containing isostichs trail the absorption peak for each pyrimidine cluster of calf thymus marker in both gradients, and show increased heterogeneity due to the difference in pKi between TdR and BUdR. Differences between the elution patterns of the B-DNA and B(F)-DNA hydrolysates are clearly apparent, however. Compare the distribution of the labeled components in each column corresponding $t_{0}$ marker peaks 3,4 , and 5 by noting the positions of the maxima and minima of each labeled isostich with reference to the position of a marker isostich; the $B(\mathrm{~F})$-DNA peaks are skewed to the right, and the radioactivity in B-DNA does not separate into distinct peaks as far along the gradient as the B(F)-DNA sample. Replicate experiments on independent samples confirmed that qualitative differences between the elution profiles of $\mathrm{B}-\mathrm{DNA}$ and $\mathrm{B}(\mathrm{F})-\mathrm{DNA}$ can be resolved to provide a direct comparison of differential BUdR incorporation in these DNAs.

The pattern of BUdR incorporation in the pyrimidine isostichs of B-DNA and $\mathrm{B}(\mathrm{F})$-DNA can also be compared by determining the fraction of the total radioactivity within each isostich species. There was, however, an unexpected problem that precluded an estimate of total recoverable radioactivity for the samples analyzed under the conditions used for Figs. 2 and 3. A fluorescent substance was washed from the columns when I $M \mathrm{LiCl}$ was added, so liquid scintillation could not be used to estimate the longer pyrimidine stretches that are usually released from the column at this salt concentration. However, elution of the $A_{260}$ fraction with $\mathrm{I} M \mathrm{LiCl}$ in proportion to the other isostichs was maintained for these columns, and the difficulty was not encountered with the earlier BUdR columns of shorter length. In order to utilize information from all the B-DNA and $\mathrm{B}(\mathrm{F})$-DNA samples, it was therefore necessary to tabulate the data so that the radioactivity recovered with $\mathrm{I} M \mathrm{LiCl}$ was not required. This was done by limiting consideration of the data to radioactivity recovered through the pentanucleotide tracts, and determining the fraction of this radioactivity included in individual isostichs $\mathrm{I}$ to 5 . The procedure was applied to the DNA samples containing a TdR label as well as to the B-DNA and B(F)-DNA samples, and the per cent values are given in Table II. It should be stressed that regardless of the difficulty in completing all of the runs through the final $\mathrm{LiCl}$ wash, both the $\mathrm{B}-\mathrm{DNA}$ and $\mathrm{B}\left(\mathrm{I}^{\mathrm{*}}\right)-\mathrm{DNA}$

TABLE $1 \mathrm{I}$

PER CENT DISTRIBUTION OF RADIOACTIVITY AMONG PYRIMIDINE ISOSTICHS I TO 5

\begin{tabular}{|c|c|c|c|c|c|c|c|}
\hline Sample & No. & $I$ & 2 & 3 & + & 5 & Total cpm \\
\hline \multirow[t]{4}{*}{ T.DNA } & I & 27.90 & 26.58 & 21.20 & I 4.95 & $9 \cdot 37$ & 24755 \\
\hline & 2 & 26.47 & 27.11 & $22.0 \mathrm{I}$ & 14.73 & 9.68 & $37+420$ \\
\hline & 3 & 26.19 & $27 \cdot 24$ & 21.64 & 14.96 & 9.97 & 78935 \\
\hline & 4 & 25.63 & $27 \cdot 4^{2}$ & 21.90 & 14.88 & 10.17 & 1.57510 \\
\hline \multirow[t]{3}{*}{ T(F)-DNA } & 1 & 25.07 & $29.9 \mathrm{I}$ & 22.83 & 14.18 & S.oI & 116025 \\
\hline & 2 & 27.37 & 26.44 & 21.2 .3 & I $4 \cdot 4^{1}$ & 10.54 & 10617.5 \\
\hline & 3 & 23.57 & 28.89 & 22.53 & 55.57 & $9 \cdot 43$ & 38575 \\
\hline \multirow[t]{4}{*}{ B-DNA } & I & 24.52 & 27.93 & 22.89 & $15 \cdot 35$ & $9 \cdot 31$ & $550+5$ \\
\hline & 2 & 25.80 & 27.80 & 23.84 & 14.88 & 7.68 & 39220 \\
\hline & 3 & $24 \cdot 32$ & 28.74 & 22.76 & 14.88 & 9.30 & 255800 \\
\hline & 4 & 27.30 & 29.00 & 23.72 & 12.30 & 7.68 & $22307^{\circ}$ \\
\hline \multirow[t]{3}{*}{$B\left(I^{i}\right)-D N A$} & 1 & 28.06 & 27.27 & 21.62 & 14.37 & 8.68 & 12672.5 \\
\hline & 2 & 30.50 & 29.29 & 21.16 & 12.68 & 6.37 & 300655 \\
\hline & 3 & 30.27 & 29.99 & 20.48 & 12.92 & 6.33 & 656560 \\
\hline
\end{tabular}


samples represented homogeneous sets for the first five isostichs when tested by the $\chi^{2}$ test of homogeneity.

Since the total cpm for each DNA sample was different, the per cent values for radioactivity were transformed to corresponding angular values ${ }^{2}$, and mean angular values for isostichs $x$ to 5 in T-DNA, T(F)-DNA, B-DNA, and $B(F)-D N A$ were then calculated. The individual mean values of the isostichs in each DNA group were compared with the corresponding means of the isostichs in the other three DNA groups by $t$ statistics, and the results of these comparisons are summarized in Table III. The contrast between the mean values of isostichs I to 5 in T-DNA and T(F)DNA did not show any significant differences. A similar contrast of the mean values of T-DNA and B-DNA indicated that the values for isostichs 2 and 3 differ significantly, and isostichs $\mathrm{I}$ and 5 differ in the T-DNA vs. B(F)-DNA contrast. The mean values

TABLE III

COMPARISON OF PYRIMIDINE ISOSTICH DISTRIBUTIONS IN DROSOPHILA DNA SAMPLES

\begin{tabular}{|c|c|c|c|c|c|}
\hline & \multicolumn{5}{|c|}{ Mean angular values for isostich percentages ( \pm S.E.) } \\
\hline & $I$ & 2 & 3 & 4 & 5 \\
\hline T-DNA & $31.01 \pm 0.32$ & $31.36 \pm 0.12$ & $27.76 \pm 0.12$ & $22.70 \pm 0.14$ & $18.24 \pm 0.17$ \\
\hline$T(F)-D N A$ & $30.21 \pm 0.73$ & $32.20 \pm 0.66$ & $28.11 \pm 0.34$ & $22.56 \pm 0.35$ & $17.76 \pm 0.7^{2}$ \\
\hline B-DNA & $30.31 \pm 0.45$ & $32.18 \pm 0.19$ & $28.86 \pm 0.19$ & $22.25 \pm 0.5^{8}$ & $16.93 \pm 0.4^{8}$ \\
\hline \multirow[t]{3}{*}{$B(F)-D N A$} & $32.96 \pm 0.49$ & $32.4^{8} \pm 0.5^{2}$ & $27.34 \pm 0.23$ & $2 \mathrm{I} .4^{\circ} \pm 0.44$ & $15.44 \pm 0.85$ \\
\hline & \multicolumn{5}{|c|}{ Comparisons of Means ( $t$ Statistics) } \\
\hline & $T$ & 2 & 3 & 4 & 5 \\
\hline \multicolumn{6}{|l|}{ Comparison } \\
\hline $\begin{array}{r}\mathrm{T} \text { os. } T(\mathrm{~F}) \\
(\mathrm{df} 5)\end{array}$ & I. I 212 & $\mathbf{I} \cdot 47^{8 I}$ & 1.0975 & $0.4^{1} 7^{6}$ & 0.7528 \\
\hline $\begin{array}{l}\text { Tws. } \mathrm{B} \\
(\mathrm{df} 6)\end{array}$ & I. 2684 & $3 \cdot 7^{022} 2^{\mathrm{a}}$ & $4.9663^{b}$ & 0.7557 & $2.559 \mathrm{I}$ \\
\hline $\begin{array}{r}\mathrm{T} \text { ขs. } \mathrm{B}(\mathrm{F}) \\
(\mathrm{df} 5)\end{array}$ & $3 \cdot 5^{196^{\mathrm{a}}}$ & 2.4617 & 1.7229 & $3.194 \mathrm{I}$ & $3.8055^{\mathrm{a}}$ \\
\hline $\begin{aligned} & \mathrm{B} v s . \mathrm{B}(\mathrm{F}) \\
&(\mathrm{df} 5)\end{aligned}$ & $3.9362^{a}$ & $0.6 \mathrm{I} 54$ & $5 . \mathrm{I} 220^{\mathrm{b}}$ & I.0928 & 1.6363 \\
\hline
\end{tabular}

Level of Significance: a $P<0.02 ; \mathrm{b} P<0.01 ; \mathrm{df}$, degrees of freedom.

for isostichs I and 3 of B-DNA are significantly different from these isostichs in B(F)DNA. It should be noted that in this statistical analysis each isostich has been considered an independent variate, but in reality changes in per cent cpm of one isostich in the sample are bound to adjust the other four values in the sample since the values are based on the total of five values. Therefore, a significant difference between the mean values for a given fraction reflects a difference in pattern of the isostichs $I$ to 5 in the two DNA groups being compared. In the case of the B-DNA and B(F)-DNA samples this statistical analysis provides an independent evaluation that supplements the elution profile differences observed between the two samples.

DISCLSSION

Growth lesions in the form of supernumerary tissues and bristles are found in the adult flies when Drosophila larvae are pulse-treated with BUdR in the presence of an inhibitor of thymidylate synthetase ${ }^{19,23}$. Since treatment with BUdR is considerably less effective in lesion induction and inhibition of thymidylate synthetase does not 
induce these lesion types ${ }^{20}$, it was suggested that BUdR incorporation in DNA is the primary cause of the lesions and inhibitors of the thymidylate synthetase play a subsidiary role in achieving incorporation of BUdR that is morphogenically effective ${ }^{21}$. An increase in BUdR incorporation in DNA is generally obtained by blocking dTMP synthesis, and increased lesion frequency in Drosophila would, of course, be anticipated as the amount of analog substituted in DNA is increased ${ }^{5,18,20}$. In CsCl pycnographic comparisons of $\mathrm{B}-\mathrm{DNA}$ and $\mathrm{B}(\mathrm{F})$-DNA obtained under identical conditions, the latter samples invariably contained more DNA molecules in the denser regions of the gradients than the former samples ${ }^{22}$. The question whether these differences between the BUdR containing DNA samples reflected qualitative distinctions in sites of BUdR incorporation as well as quantitative differences remained ${ }^{18}$, and the present study was directed to answering this question.

When the fractions of radioactivity in pyrimidine isostich 3 of B-DNA and B(F)-DNA are compared, the two show significant differences $(P<0.0 \mathrm{I})$, and comparison of the elution profiles with reference to calf thymus marker peaks 3 and 4 confirms qualitative differences between the trinucleotide components in the two DNAs. For B-DNA the radioactivity peak elutes with the descending shoulder of the $A_{\text {260 }}$ peak 3 , whereas for $\mathrm{B}(\mathrm{F})$-DNA the maximum radioactivity of the trinucleotide peak locates with the ascending front of the $A_{260}$ peak 4 . Since the mobility of the mononucleotides can be judged to fall in the elution order thymine $>$ cytosine $>\mathrm{BU}$ for these column conditions, it follows that the greater the BU number in a given chain length, the slower the mobility of the substituted molecule on the column. Thus, the trinucleotide species front should be $\mathrm{BC} /$ pyrimidine/pyrimidine and the trailing end should be $\mathrm{BU} / \mathrm{BU} / \mathrm{BU}$. In comparing the trinucleotide peaks in B-DNA and $\mathrm{B}(\mathrm{I})$ DNA, it is clear that in the latter, more pyrimidine sites have accepted $B L$. The same conclusion can be applied to the tetranucleotide species and the isostichs of higher order, clearly indicating qualitative differences between B-DNA and B(F)-DNA.

It is generally accepted that dTTP generated via the salvage pathway enters the same pool as dTTP formed ria the synthetic pathway ${ }^{10}$. Therefore, the TdRlabeled pattern of the pyrimidine isostichs can be accepted as the standard pattern for D. melanogaster DNA, and we can inquire whether BUdR follows this normal pattern in its incorporation in Drosophila DNA by examining the distribution of $\mathrm{BU}$ among the pyrimidine isostichs. The quantitative differences in the patterns of the T-DNA and B-DNA sets indicate that BUdR is not accepted as a random alternate for TdR in DNA when the two nucleosides are given under comparable conditions and thymidylate synthetase is operating normally. Even when the synthetic pathway is blocked by $\mathrm{FU}$ treatment to increase the incorporation of the fraudulent base in DNA, the pattern of its distribution does not coincide precisely with that of the distribution of exogenous TdR. Whether the difference between the B-DNA isostich pattern and the $B(F)$-DNA pattern represents competition between dTTP and ABITP in pairing with the adenine residues at the level of the DNA template or selection by the intervention of other factors such as DNA associated proteins, the overall effect appears as a restriction on sites where BUdR can be incorporated.

Analysis of the sizes of the supernumerary growths and bristle clusters induced by a 6 -h pulse of $\mathrm{BUdR}+\mathrm{FU}$ at various intervals of larval life has shown that earlier treatment results in large lesions while treatment of older larvae produces small lesions, otherwise the types of lesions are similar. Since lesions can be induced by pulse treat- 
ment as early as the first instar when the number of imaginal disc cells is small, and a lengthy period of cell multiplication (8-I2 cycles) in the absence of analog precedes differentiation of the imaginal disc cells during pupal metamorphosis, these data support the hypothesis that an altered phene initiated by the analog in an imaginal disc cell is transmitted to its descendant cells during the growth of the imaginal disc; the presence of BUdR in all these cells at the same sites of gene loci is less likely to be the case $^{22}$. BUdR is mutagenic by virtue of its incorporation in DNA so it seems reasonable to consider that the developmental lesions in Drosophila are the result of mutational events subsequent to BUdR incorporation in DNA of the imaginal disc cells. In a diploid cell expression of a mutant phene will be limited to dominant type events and mutations of regulatory sites which will have dominant effects in progeny cells during development and differentiation of the soma. If lesion induction by BUdR is a result of mutational events due to its incorporation in DNA, then these events must be favored by the conditions imposing forced incorporation of the analog when the normal base is deficient for DNA synthesis.

Comparison of the events associated with the induction of MIV by IUdR and BUdR shows some similarity to the induction of growth lesions in the somatic cells of Drosophila. Incorporation of IUdR or BUdR into cellular DNA of AKR cell lines plays a vital role in the activation of $M L V$, and when the analog incorporation in DNA is enhanced by simultaneous treatment with FUdR, the proportion of cells induced to produce virus is significantly increased ${ }^{32}$. Integration of the viral genome in the DNA of AKR mice has been demonstrated ${ }^{8}$ and mapped in linkage group I (ref. 24). TEICH et $a l .^{32}$ consider mutational events as an unlikely mechanism for the high rates of viral induction. On the other hand, if several loci with regulatory elements are involved in the expression of a given phenotypic event and the assay system is selectively geared to reveal only the final event, high levels of response at the cell level might be detected as a result of mutational events. Similar considerations apply to the analysis of the BUdR and IUdR effects on Drosophila imaginal disc cells. The morphological events have been grouped as bristle deviants and supernumerary tissues for purposes of classification and many gene loci regulate the formation of a bristle or any other tissue in the body. Mutation at any one of the regulatory sites might alter the normal prospective fate of an imaginal disc cell, and the result will be a high frequency of a similar phenotypic event.

\section{ACKNOWLEDGEMENTS}

We are thankful to Mr. JUNAD M. RıZKI for his generous help with the statistical analysis, and to Dr. Rowland H. DAvis for helpful comments in reviewing the manuscript.

This investigation was supported by Public Health Service Research Grant No. CA-I2600 from the National Cancer Institute.

\section{REFERENCES}

I Aaronson, S. A., G. J. Todaro AND E. M. SCOLnick, Induction of murine C-type viruses from clonal lines of virus-free BALB/3T3 cells, Science, I 74 (I97I) I 57-1 59.

2 Burss, C. I., Statistics in Biology, Vol. I, McGraw Hill, New Ygrk, I967.

3 Burton, K., Sequences of nucleotides in deoxyribonucleic acid containing 5-bromouracil, Biochim. Biophys. Acta, 55 (1962) 4 I2-4 I 5 . 
+ Burton, K., AnD G. B. Petersen, The frequencies of certain sequences of nucleotides in deoxyribonucleic acid, Biochem. $J ., 75$ (1960) I 7-27.

5 CARPENTER, N., Properties and inhibition of thymidylate synthetase in Drosophila melanogaster, J. Insect Physiol., 20 (1974) I 389-I 40I.

6 Cerny, R., E. Cerna and J. H. Spencer, Nucleotide clusters in deoxyribonucleic acids, IV. Pyrimidine oligonucleotides of bacteriophage SizsuNi 5 DNA and replicative form DNA, f. Mol. Biol., 46 (1969) I $45^{-1} 5^{6 .}$

7 ChargafF, E., What really is DNA ? Remarks on the changing aspects of a scientific concept. in J. N. Davidson and W. E. Cohn (Eds.), Progress in Nucleic Acid Research and Molecular Biology, Vol. 8, Academic Press, New York, 1968, pp. 297-333.

i Chattopadhyay, S. K., D. R. Lowy, N. M. Teich, A. S. Levine and W. P. Rowe, Evidence that the AKR murine-leukemia-virus genome is complete in DNA of the high-virus AKR mouse and incomplete in the DNA of the "virus-negative" NIH mouse, Proc. Natl. Acad. Sci.

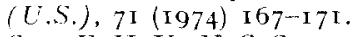

9 CHU, E. H, Y., N. C. Sun and C.C. Chang, Induction of auxotropic mutations by treatment of Chinese hamster cells with 5-bromodeoxyuridine and black light, Proc. Natl. Acad. Sci (U.S.), $69(\mathrm{rg7}) 3459-3463$.

1o Cleaver, J. E., Thymidine Metabolism and Cell Kinetics, North-Holland, Amsterdam, 1967.

i coleman, J. R., A. W. Coleman and E. J. H. Hartline, A clonal study of the reversible inhibition of muscle differentiation by the halogenated thymidine analog 5 -bromodeoxyuridine, Develop. Biol., I9 (1969) $527-54$.

I 2 DrakE, J. W., The Molecular Basis of Mutation, Holden-Day, San Francisco, 1970.

1.3 FREESE, E.., The specific mutagenic effect of base analogues of phage T 4 , J. Mol. Biol., I (I959) $87-105$.

If Hill, B. T., A. Tsuboi And R. BAserga, Effect of 5-bromodeoxyuridine on chromatin transcription in conffuent fibroblasts, Proc. Nall. Acad. Sci. (U.S.), 7 I (1974) $455^{-4}+59$.

1.5 LenvitT, D., AND A. DORfman, The irreversible inhibition of differentiation of limb-bud mesenchyme by bromodeoxyuridine, Proc. Nal. Acad. Sci. (U.S.), 69 (I972) I $253-1257$.

16 LIN, S., AND A. D. RIGGS, Lac operator analogues: bromodeoxyuridine substitution in the lac operator affects the rate of dissociation of the lac repressor, Proc. Natl. Acad. Sci. (L.S.) 69 (I 972 ) $2574^{-2576 .}$

I 7 Lowy, D. R., W. P. Rowe, N. Teich and J. W. Harteey, Murine leukemia virus: high frequency activation in vitro by 5 -iododeoxyuridine and 5 -bromodeoxyuridine, Science, I74 ( $197 \mathrm{I})$ I $55^{-\mathrm{I}} 5^{6}$

is Rizki, R. M., H. A. Douthit and 'T. M. Rizki, Morphogenic effects of halogenated thymidine analogs on Drosophila 1I. Incorporation of 5 -bromodeoxyuridine into DNA, Mutation Res., I 4 (I972) IOI-III.

19 RizKı, R. M., AND T. M. RIzKI, Somatic cell lesions induced by the base analog 5-bromodeoxyuridine, Cancer Res., 29 (I 959 ) $20 \mathrm{I}-208$.

20 Rizki, R. M., and T. M. RIzki. Morphogenic effects of halogenated thymidine analogs on Drosophila III. 5-Iododeoxyuridine, Experientia, 28 (1972) 329-332.

2 I Rizki, R. M., AND T. M. Rizki, The role of thymidine synthetase inhibitors in bromodeoxyuridine-induced neoplasia in Drosophila, Cancer Kes., 33 ( $\mathrm{ra73}$ ) 2856-286 $\mathrm{I}$.

22 Rizki, R. M., AN1 'T. M. Rızi, Morphogenic effects of halogenated thymidine analogs on Drosophila, VI. Causal analysis of bromodeoyxuridine induced growth lesions, Differentiation $3(1975) 133-\mathrm{I}+2$.

23 Rizki, T. M., R. M. Rizki axi H. A. Douthit, Morphogenic effects of halogenated thymidine analogs on Drosophila I. Quantitative analysis of lesions induced by 5 -bromodeoxyuridine and 5-fluorouracil, Biochem. Genet., 6 (1972) 83.97.

2t Rowe, W. P., J. W. Hartley axi T. Bremner, Genetic mapping of a murine leukemial virusinducing locus of AKR mice, Science, is7 (1972) 860-862.

25 RUnNer, R., M. Ledoux AN1) A. Mazels, Distribution of pyrimidine oligonucleotides in strands of $\mathrm{L}$ and $\mathrm{H}$ of Bacillus subtilis DNA, Proc. Natl. Acad. Sci (U.S.), 69 (ro7z) $27+5-27+9$.

26 SCHUBER'T, I )., AND F. JACOB, 5-Bromodeoxyuridine-induced differentiation of a neuroblastoma, Proc. Natl. Acad. Sci. (U.S.), 67 (1970) $247^{-25}+$.

27 Silagi, S., D. Beju, J. Wrathall ani E. DeHarvan, Tumorigenicity, immunogenicity, and virus production in mouse melanoma cells treated with 5-bromodeoxyuridine, Proc. Natl. Acad. Sci. (U.S.), $69(1972) 3+43-3+47$.

28 Simon, E. H., Effects of 5-bromodeoxyuridine on cell division and DNA replication in HeLa cells, Exptl. Cell Res., Suppl. 9 (1963) 263-269.

29 Spencer, J. H., R. E. CAPr, A. Marks ani) W. E. Mushynski, Quantitative determination of pyrimidine nucleotide clusters by a single spectrophotometric measurement, Canad. $J$. Biochem., 46 (1968) 627-630. 
30 Spencer, J. H., R. E. Cape, A. Marks and W. E. Mushynski, Nucleotide clusters in deoxyribonucleic acids, II. Investigation of methods for isolation of pyrimidine oligonucleotides, Canad. J. Biochem. 47 (1969) 329-337.

3i Stockdale, F., K. Okazaki, M. Nameroff and H. Holtzer, 5-Bromodeoxyuridine: Effect on myogenesis in vitro, Science, I46 (r 964) 533-535.

32 Teich, N., D. R. Lowy, J. W. Hartley and W. P. Rowe, Studies of the mechanism of induction of infectious murine leukemia virus from AKR mouse embryo cell lines by 5-iododeoxyuridine and 5-bromodeoxyuridine, Virology, 5I (I973) I63-I73.

33 Toliver, A., E. H. Simon and P. T. Gilham, On the mechanism of 5-bromouracil inhibition of DNA synthesis and cell division, Exptl. Cell Res., 53 (I968) 506-5I8. 